\title{
KARAKTERISTIK TEPUNG SORGUM TERMODIFIKASI DENGAN PROSES FERMENTASI DENGAN MENGGUNAKAN YEAST INDIGENOUS SORGUM
}

\author{
[Characteristic of Modified Sorghum Flours Fermented by Indigenous Sorghum Yeast]
}

\author{
Zulianatul Hidayah', Rikka Welhelmina Sir ${ }^{1}$ \\ 1Program Studi Teknologi Rekayasa Pangan, Jurusan Tanaman Pangan Dan Hortikulutra Politeknik Pertanian \\ Negeri Kupang \\ E-mail: zu_li7@yahoo.co.id (Telp;+6281333877785)
}

Diterima tanggal 22 November 2021

Disetujui tanggal 26 November 2021

\begin{abstract}
The purpose of this study was to examine the physicochemical characteristics of fermented sorghum flour using indigenous sorghum yeast. The study used a completely randomized factorial design with various fermentation times (24, 48, 72 hours) as the first factor and the concentration of indigenous sorghum yeast starter $(2.5 \%, 5 \%, 7.5 \%, 10 \%$, $12.5 \%$, and $15 \% \mathrm{w} / \mathrm{v}$ ) as the second factor in three replications. Parameters observed were physicochemical characteristics including starch content, water content, swelling power, water absorption, and bulk density. The data obtained were analyzed using analysis of variance $(A N O V A)(P<0.05)$ and Duncan's Multiple Range Test (DMRT). The results show that the best-fermented sorghum flour was obtained at 72 hours of fermentation time with a $5 \%$ starter. The sorghum flour has a starch content of $74.8 \%$, water content of $10.97 \%$, swelling power of $15.44 \mathrm{~g} / \mathrm{g}$, water absorption capacity of $67.58 \%$, and bulk density $0.6 \mathrm{~g} / \mathrm{ml}$. Modification by fermentation using indigenous sorghum yeast can improve the physical and chemical properties of sorghum flour. Based on the nutritional content of sorghum flour, it met the quality requirements of Codex Standard 173-1989 in ash, protein, fat, crude fiber, and carbohydrate contents.
\end{abstract}

Keywords:sorghum, modified, yeast indigenous, phisycal and chemical characteristik.

\begin{tabular}{l} 
ABSTRAK \\
\hline Tujuan penelitian ini adalah untuk mengkaji karakteristik fisikokimia tepung sorgum hasil fermentasi dengan \\
menggunakan yeast indigenous sorgum. Penelitian dilakukan dengan menggunakan rancangan acak lengkap pola \\
faktorial dengan lama fermentasi $(24,48,72$ jam) sebagai faktor pertama dan konsentrasi starter yeast indigenous \\
sorgum $(2,5 \%, 5 \%, 7,5 \%$ dan $10 \%, 12,5 \%$ dan $15 \%$ b/v) sebagai faktor kedua, menggunakan 3 ulangan. Parameter \\
yang diamati adalah karakteristik fisikokimia meliputi kadar pati, kadar air, sweeling power, daya serap air dan densitas \\
Kamba. Data yang diperoleh dianalisis dengan menggunakan Analisis Ragam (ANOVA) $(\mathrm{P}<0,05)$ dan uji lanjut Duncan \\
Multiple Range Test (DMRT). Hasil penelitian menunjukkan bahwa tepung sorghum terfermentasi terbaik didapatkan \\
pada perlakuan lama fermentasi 72 jam dengan jumlah starter sebanyak $5 \%$. Karakterisitik tepung sorgum ynag dimiliki \\
adalah kadar pati $74,8 \%$, kadar air $10,97 \%$, swelling power 15,44 g/g, daya serap air $67,58 \%$ dan densitas kamba 0,6 \\
g/ml. Modifikasi dengan fermentasi menggunakan yeast indigenous sorgum mampu memperbaiki sifat fisik dan kimia \\
tepung sorgum. Berdasarkan kandungan gizi pada tepung sorgum telah memenuhi syarat mutu Codex Standard $173-$ \\
1989 pada kadar, abu, protein, lemak, serat kasar dan karbohidrat.
\end{tabular}

Kata kunci: sorgum, modifikasi, yeast indigenous, sifat fisikokimia 


\section{J. Sains dan Teknologi Pangan Vol. 6, No.6, P. 4629-4639, Th. 2021}

\section{PENDAHULUAN}

Sorgum merupakan jenis tanaman yang tahan terhadap kekeringan dan juga bisa tumbuh pada tanah dengan kesuburan rendah. Sorgum banyak dibudidayakan di Nusa Tenggara Timur (NTT) karena budidaya sorgu relative lebih tahan terhadap kekeringan. Di beberapa daerah sorgum dijadikan sumber bahan pangan pokok Kandungan gizi sorgum juga tidak kalah dengan sumber panga lain seperti beras, jagung, maupun gandum. Kadar protein sorgum yang cukup tinggi yakni sekitar 10\% mengandung vitamin B1 dan juga beberapa mineral penting seperti besi.

Sorgum sangat potensial untuk dikembangkan menjadi beberapa produk olahan, bahkan sorgum mempunyai potensi untuk mengagntikan tepung terigu. Tepung terigu merupakan produk impor dimana setiap tahun permintaan akan tepung terigu semakin meningkat. pada kuartal pertama 2012 kebutuhan tepung terigu sebesar 1,22 juta ton Dengan semakin meningkatnya jumlah produk yang terbuat dari tepung terigu maka jumlah impor bahan baku tepu terigu juga meningkat. Kandungan gizi sorgum tidak kalah dengan gandum, kadar protein gandum berkisar 10-12\%, sedangkan kadar protein sorgum berkisar 10-12\%. Sorgum sangat potensial untuk dikembangkan menjadi bahan baku pengganti tepung terigu.

Fermentasi merupakan suatu proses untuk mengubah bahan dasar menjadi suatu produk oleh massa sel mikrobia. Mikrobia yang umumnya terlibat dalam proses fermentasi adalah khamir, kapang dan bakteri. Tujuan Fermentasi adalah untuk meningkatkan daya simpan, memperbaiki palatabilitas (daya penerimaan) dan memperbaiki kecernaan serta mening katkan nilai gizi (Fadlallah et al., 2010). Fermentasi sorghum secara tradisional diketahui secara nyata dapat memperbaiki sifat fungsional tepung sorghum. Proses fermentasi tepung sorghum secara signifikan mampu meningkatkan kecernaan protein dan pati, ketersediaan asam amino lysine, leucine, isoleucine dan methionin sehingga memperbaiki keseimbangan asam amino serta ketersediaan karbohidrat dan kandungan gizi lainnya (Alka et al., 2012). fermentasi sorgum dengan menggunakan bakteri asam laktat (BAL) yang dilanjutkan dengan pengeringan pada suhu $60{ }^{\circ} \mathrm{C}$ akan menurunkan $\mathrm{pH}$ tepung sorgum dan sedikit meningkatkan pati tergelatinisasi serta kekentalannya. Nilai $\mathrm{pH}$ rendah dari tepung sorgum fermentasi menyebabkan produk roti lebih bervolume dan memiliki crumb lebih lembut. Hal itu dikarenakan adanya penurunan aktivitas malt amylase dan peningkatan kapasitas pengikatan air (water holding capacity) oleh pati (Correia et al., 2010). Fermentasi khamir Saccharomyces cerevisiae dapat meningkatkan daya cerna pati secara in vitro dan meningkatkan viskositas adonan serta kapasitas pengikatan gas (Ibrahim et al., 2005). Fermentasi sorgum dengan menggunakan BAL indigenous sorgum mampu merubah sifat amilografi dari tepung sorgum (Hidayah dan kartiwan, 2017)

Pati termodifikasi adalah pati yang telah mengalami perlakuan fisik, kimia serta biologis secara terkendali sehingga mengubah satu atau lebih dari sifat asalnya, seperti suhu awal gelatinisasi, karakteristik 
selama proses gelatinisasi, ketahanan oleh pemanasan, pengasaman dan pengadukan serta kecenderungan retogradasi (Kusnandar, 2010). Sifat-sifat yang diinginkan dari pati termodifikasi adalah menghasilkan pati dengan viskositas stabil pada suhu tinggi dan rendah, daya pengental yang tahan terhadap kondisi asam sehingga pati yang telah termodifikasi akan mengalami perubahan sifat yang dapat disesuaikan untuk keperluan-keperluan tertentu (Koswara, 2009). Teknik modifikasi yang banyak dilakukan, antaranya adalah modifikasi secara fisik, kimia dan biologi. Modifikasi biologi yakni modifikasi dengan memanfaatkan mikroorgaisme tertentu (fermentasi). Pemanfaatan Bakteri Asam Lakat (BAL) L. plantarum\& S. Cerevisiae menyebabkan adanya perubahan kadar amilosa dann penurunan kadar amilomektik pati gayong akibat aktivitas mikroorganisme (Ashari et al., 2018). Modifikasi dengan fermantsi mampu meningkatkan solubility, swelling power, dan kadar karboksil tepung ubi kayu yang difermentasi dengan menggunakan L. casei (Darmawan et al., 2013). Fermentasi sorgum dengan menggunakan ragi tape mampu mengubah sifat fisik, kimia dan amilografi tepung sorgum menghasilkan tepung sorgum dengan kadar amilosa $21.62 \%$, rendemen $56.54 \%$, nilai pH 5.74 , nilai swelling power $8.86 \mathrm{~g} / \mathrm{g}$, nilai kelarutan $42.28 \%$, nilai kecerahan 74.13 , derajat hue $65.70^{\circ}$ dan viskositas $1840.67 \mathrm{cP}$.

\section{BAHAN DAN METODE}

\section{Bahan}

Bahan yang digunakan adalah sorgum varietas lokal yang diperoleh dari kabupaten Malaka Nusa Tenggara Timur. Bahan kimia yang digunakan meliputi $\mathrm{HCl}$ (Merck), $\mathrm{NaOH}$ (Merck), Ka-Na tartrat(Merck), asam dinitrosalisilat (DNS) (Merck) dan glukosa standar(Sigma), media Potato dextrose broth (Merck)

\section{Tahapan Penelitian}

\section{Preparasi Biji Sorghum}

Biji sorghum yang digunakan adalah varietas lokal yang diperoleh dari desa Kletek kabupaten Malaka Nusa Tenggara Timur. Biji sorghum disosoh atau di pecah, dipisahkan kulit dan bijinya dengan mesin penyosoh. Biji tanpa kulit kemudian digunakan untuk proses fermentasi.

\section{Pembuatan Starter}

Starter dibuat dari perbanyakan kultur yeast yang diisolasi dari sorgum. Starter dibuat dengan menumbuhkan yeast kedalam medium PDB (Potato Dextrose Broth) secara bertahap. Satu ose biakan yeast dimasukkan ke dalam mikrotube berisi $1 \mathrm{ml} \mathrm{PD}$ broth secara aseptis kemudian dinkubasi pada suhu $37^{\circ} \mathrm{C}$ selama 48 jam. Setelah 48 jam inkubasi, $1 \mathrm{ml}$ inokulum diinokulasikan kembali ke dalam tabung reaksi berisi $10 \mathrm{ml} \mathrm{PD}$ broth secara aseptis kemudian diinkubasi pada suhu $37^{\circ} \mathrm{C}$ selama 48 jam. Selanjutnya $10 \mathrm{ml}$ PD 
broth secara aseptis diinokulasikan kembali ke dalam Erlenmeyer $100 \mathrm{ml}$ PD broth secara aseptis kemudian diinkubasi pada suhu $37^{\circ} \mathrm{C}$ selama 48 jam dan siap digunakan sebagai starter.

\section{Fermentasi Sorghum (Alka et al., 2012)}

Proses fermentasi biji sorghum dilakukan dengan modifikasi metode Alka et al. (2012). Biji sorghum yang akan difermentasi, terlebih dahulu dicampur dengan akuades dengan perbandingan biji sorghum dan akuades adalah 1:2 (w/v). Campuran biji sorghum dan akuades kemudian dinokulasikan starter dengan variasi konsentrasi starter 2,5, 5, 7,5, 10, 12,5 dan 15\% (v/b) dan lama fermentasi 24,48 dan 72 jam, masing - masing perlakuan menggunakan 3 ulangan. Setelah fermentasi, biji sorghum ditiriskan dan dikeringkan menggunakan oven pada suhu $60^{\circ} \mathrm{C}$ selama kurang lebih $15 \mathrm{jam}$. Setelah kering, biji sorghum digiling dan diayak menggunakan ayakan dengn ukuran 80 mesh untuk mendapatkan tepung yang homogeny. Tepung sorghum terfermentasi yang didapat selanjutnya dianalisis karakteristik fisikokimianya. Parameter kimia yang diamati meliputi kadar air metode thermogravimetri (AOAC dalam Sudarmadji et al.,1997), Kadar Pati (AOAC dalam Sudarmadji et al.,1997) sedangkan parameter fisik yang diamati meliputi viskositas menggunakan viscoamilografi dan swelling power (Leach et al.,1959), analisa daya serap air metode AACC (2000), bulk density (Muchtadi, 1992).

\section{Rancangan Penelitian}

Penelitian ini menggunakan Rancangan Acak Lengkap (RAL), dengan dua factor yakni Faktor konsentrasi jumlah starter $(2.5 \%(\mathrm{~S} 1), 5 \%(\mathrm{~S} 2), 7.5 \%(\mathrm{~S} 3), 10 \%(\mathrm{~S} 4), 12.5 \%(\mathrm{~S} 5)$ dan $15 \%(\mathrm{~S} 6)$, faktor kedua adalah lama fermentasi (24 jam (T1), 48 jam (T2) dan 72 jam (T3), semua perlakuakn diulang sebanyak 3 kali ulangan.

\section{Analisis Data}

Analisis data dalam penelitian ini diperoleh dari hasil penilaian organoleptik penerimaan panelis terhadap perbedaan komposisi tepung rumput laut dan tepung kentang pada produk produk roti tawar. Data dianalisis dengan menggunakan sidik ragam (Analysis of Varian), hasil penilaian organoleptik yang berpengaruh nyata terhadap variabel pengamatan, dilanjutkan dengan uji Duncan's Multiple Range Test (DMRT) pada taraf kepercayaan $95 \%(a=0,05)$.

\section{HASIL DAN PEMBAHASAN}

\section{Kadar air}

Kadar air merupakan salah satu syarat mutu pentingpada tepung-tepungan dan bahan pangan lainnya karenaber hu bung an dengan daya awet tepung. Fennema (1996)menyebutkan air yang terdapat dalam bentuk bebas dapatmenyebabkan kerusakan bahan makanan misalnya proses mikrobiologis, kimiawi, 
enzimatik maupun penunjang aktifitas serangga perusak. Kadar air tepung sorgum terfermentasi pada penelitian ini berkisar antara 10,35\% dan 11,5\% (Tabel 1).

Tabel 1. Kadar Air tepung sorghum terfermentasi menggunakan starter Yeast indigenous sorgum dengan variasi konsentrasi starter dan lama fermentasi

Kadar Air (\%) pada jumlah starter yang digunakan (\% b/v)

lama

\begin{tabular}{llllll}
\hline $2,50 \%$ & $5 \%$ & $7,50 \%$ & $10 \%$ & $12,50 \%$ & $15 \%$
\end{tabular}

fermentasi

\begin{tabular}{lllllll}
\hline $24 \mathrm{jam}$ & $10.42 \pm 0.07 \mathrm{Aa}$ & $10.42 \pm 0.07 \mathrm{Aa}$ & $10.43 \pm 0.07 \mathrm{Aa}$ & $10.43 \pm 0.07 \mathrm{Aa}$ & $10.43 \pm 0.07 \mathrm{Aa}$ & $10.43 \pm 0.07 \mathrm{Aa}$ \\
$48 \mathrm{jam}$ & $10.89 \pm 0.02 \mathrm{Ab}$ & $10.89 \pm 0.02 \mathrm{Ab}$ & $10.90 \pm 0.02 \mathrm{Ab}$ & $10.90 \pm 0.02 \mathrm{Ab}$ & $10.90 \pm 0.02 \mathrm{Ab}$ & $10.89 \pm 0.02 \mathrm{Ab}$ \\
$72 \mathrm{jam}$ & $11.01 \pm 0.27 \mathrm{Ac}$ & $11.01 \pm 0.27 \mathrm{Ac}$ & $11.02 \pm 0.27 \mathrm{Ac}$ & $11.02 \pm 0.27 \mathrm{Ac}$ & $11.02 \pm 0.27 \mathrm{Ac}$ & $11.02 \pm 0.27 \mathrm{Ac}$
\end{tabular}

Keterangan: Subscript yang sama pada kolom yang sama dan superscript yang sama pada baris yang sama menunjukkan tidak berbeda nyata pada taraf kepercayaan $95 \%$.

Hasil analisis statistik menunjukkan bahwa secara umum penggunaan konsentrasi starter 2,5, 5, 7,5, 10, 12,5 dan $15 \%$ memberikanhasil yang tidak berbeda nyata $(P>0,05)$ terhadap kadar air,sedangkan variasi lama fermentasi 24,48 dan 72 jam memberikan hasil yang berbeda nyata $(P<0,05)$. Kadar airtepung sorghum terfermentasi pada penelitian ini memenuhi standar tepung komersial dalam pada umumnya seperti syarat mutu tepung sorghum dengan kadar air maksimal 14\% (b/b) dalam SNI 01-3157 (Badan Standardisasi Nasional, 1992). Selama proses fermentasi adanya penyerapan air ke dalam bahan yang menyebabkan adanya kenaikan akdar air. Hal yang sama dinyatakan oleh Ojokoh et al.(2020) bahwa sorgum yang difermentasi mempunyai kadar air yang lebih tinggi bila dibandingkan sorgum tanpa fermentasi.

\section{Kadar pati}

Pati terdiri atas amilosa dan amilopektin. Sifat kimia pati dipengaruhioleh perbandingan komposisi amilosa dan amilopektin (Suarni, 2005). Hasil analisis statistik menunjukkan bahwa secara umum penggunaan konsentrasi starter 2,5, 5, 7,5, 10, 12,5 dan 15\% memberikanhasil yang tidak berbeda nyata $(P>0,05)$ terhadap kadar pati,sedangkan variasi lama fermentasi 24,48 dan 72 jam memberikan hasil yang berbeda nyata $(P<0,05)$. Kadar pati pada sorgum yang difermentasii dengan menggunakan starter sebanyak $15 \%$ adalah 70,93 sedangkan kadar pati pada sorgum yang difermentasi dengan menggunakan starter sebanyak $2,5 \%$ adalah $76.04 \%$ (Tabel 2 ). 
Tabel 2. Kadar Pati tepung sorghum terfermentasi menggunakan starter Yeast indigenous sorgum dengan variasi konsentrasi starter dan lama fermentasi

$$
\text { Kadar Pati (\%) pada jumlah starter yang digunakan (\% b/v) }
$$

\begin{tabular}{|c|c|c|c|c|c|c|}
\hline $\begin{array}{l}\text { ama } \\
\text { ermentasi }\end{array}$ & $2,50 \%$ & $5 \%$ & $7,50 \%$ & $10 \%$ & $12,50 \%$ & $15 \%$ \\
\hline ism & $76.16 \pm 0.01 \mathrm{Aa}$ & $76.18 \pm 0.01 \mathrm{Aa}$ & $76.17 \pm 0.01 \mathrm{Aa}$ & $76.18 \pm 0.01$ & $76.18 \pm 0.01 \mathrm{Aa}$ & $76.18 \pm 0.0$ \\
\hline & $75.98 \pm 0.01 \mathrm{Ab}$ & $74.98 \pm 0.01 \mathrm{Ab}$ & $74.97 \pm 0.01 \mathrm{Ab}$ & $74.96 \pm 0.01 \mathrm{Ab}$ & $74.96 \pm 0.01 \mathrm{Ab}$ & $74.96 \pm 0.01 \mathrm{Ab}$ \\
\hline jam & $72.12 \pm 0.01 \mathrm{Ac}$ & $72.10 \pm 0.01 A c$ & $72.11 \pm 0.01 \mathrm{Ac}$ & $72.11 \pm 0.01 \mathrm{Ac}$ & $72.11 \pm 0.01 \mathrm{Ac}$ & $72.11 \pm 0.01 \mathrm{Ac}$ \\
\hline
\end{tabular}

Keterangan: Subscript yang sama pada kolom yang sama dan superscript yang sama pada baris yang sama menunjukkan tidak berbeda nyata pada taraf kepercayaan $95 \%$.

Perlakuan lama fermentasi berpengaruh menghasilkan kadar total pati sorgum. Sorgum yang difermentasi selama 72 jam mempunyai kadar pati yang lebih rendah dibandingkan pati yang difermentasi selama 24 jam. Lebihrendahnya kadar total pati pada tepung sorgum fermentasi disebabkan oleh aktivitas enzim amilase dari yeast dalam menghidrolisis komponen amilosa pada pati sorgum selama fermentasi (Setiarto et al. 2016). Amilase menghidrolisis ikatan linier $a-1,4 g$ likosidik pada amilosa secara acak menghasilkan campuran dekstrin, maltosa, dan glukosa (Bhanwar \&Ganguli 2014).

\section{Swelling Power}

Swelling power adalah kekuatan tepung untuk mengembang. Faktor-faktor yang mempengaruhi antara lain perbandingan amilosa-amilopektin, panjang rantai dan distribusi berat molekul. Swelling power berkaitan dengan proses gelatinisai pati yang menunjukkan adanya pemecahan ikatan intramolekuler hydrogen dalam daerah kristalin dan penyerapan air oleh ikatan hydrogen, penyerapan air oleh polisakarida selain pati dan protein (Wani et al., 2011). Analisis swelling power ini dilakukan untuk mengetahui seberapa banyak pengembangan yang dapat terjadi apabila pati dimasak. Bila pati dalam air dipanaskan, air akan menembus granula pati dari luar menuju bagian dalam hingga granula terisi air sepenuhnya (terhidrasi). Setelah terhidrasi, ikatan hidrogen antara amilosa dan amilopektin akan berusaha mempertahankan integritas granula dan mulai terjadi pembengkakan (swelling) dari inti granula. Nilai swelling power ini dipengaruhi beberapa faktor, salah satunya adalah kandungan amilosa pada tepung yang digunakan. Semakin tinggi kandungan amilosa, maka akan semakin rendah tingkat swelling power.

Peningkatkan daya kembang akibat pemanasan pada suhu yang semakin tinggi disebabkan kadar amilosa yang semakin rendah atau amilopektin lebih tinggi. Hasil analisis statistik menunjukkan bahwa secara umum penggunaan konsentrasi starter 2,5, 5,7,5, 10, 12,5 dan 15\% memberikan hasil yang berbeda nyata 
$(P>0,05)$ terhadap swelling power, demikian juga dengan variasi lama fermentasi 24,48 dan 72 jam memberikan hasil yang berbeda nyata $(P<0,05)$. Berdasarkan hasil Uji lanjut bisa dilihat pada Tabel 1.

Tabel 1. Swelling Power tepung sorghum terfermentasi menggunakan starter Yeast indigenous sorgum dengan variasi kensentrasi starter dan lama fermentasi

Swelling Power (g/g) pada jumlah starter yang digunakan (\% b/v)

\section{lama}

fermentasi

$2,5 \%$

$5 \% \quad 7,5 \%$

$10 \%$

$12,5 \%$

$15 \%$

24 jam

$15.28 \pm 0,2 \mathrm{BC}$

$15.04 \pm 0,2 B C$

$14.79 \pm 0,2 \mathrm{Aa}$

$14.84 \pm 0,2 \mathrm{Aa}$

$15.06 \pm 0,2 \mathrm{Bb}$

$14.76 \pm 0,2 \mathrm{Aa}$

48 jam

$15.17 \pm 0,14 \mathrm{AC}$

$15.22 \pm 0,14 \mathrm{Bd}$

$14.9 \pm 0,14 \mathrm{Ba}$

$14.97 \pm 0,14 \mathrm{Aa}$

$14.87 \pm 0,14 \mathrm{Aa} \quad 15.01 \pm 0,14 \mathrm{Bb}$

72 jam

$15.14 \pm 0,18 \mathrm{Ab}$

$15.44 \pm 0,18 \mathrm{Cd}$

$15.1 \pm 0,18 \mathrm{Bb}$

$15.01 \pm 0,18 \mathrm{Aa}$

$15.27 \pm 0,18 \mathrm{Cc}$

$15.43 \pm 0,18 \mathrm{Cd}$

Keterangan: Subscript yang sama pada kolom yang sama dan superscript yang sama pada baris yang sama menunjukkan tidak berbeda nyata pada taraf taraf kepercayaan $95 \%$.

Hasil penelitian menunjukkan bahwa dengan semakin meningkatnya jumlah starter yang digunakan, kemampuan mengembang (swelling power) akan semakin menurun. Hal yangs ama dilaporkan oleh Buwono et al.(2018) bahwa dengan semakin meningkatnya konsentras L. fermentum dalam fermentasi pisang (Musa balbisiana) menyebabkan menurunnya kemampuan mengembang (sweeling power) dari tepung pisang. Penurunan kemampuan mengembang (swelling power) karena adanya enzim yang dihasilkan oleh yeast yang akan menghidrolisis area amorf pada granula pati. Adanya hidrolisis ini akan menyebabkan penurunan daya penyerapan air sehingga swelling power menurun. Numfor et al.(1995) menjelaskan bahwa pada area amorf gugus $\mathrm{OH}$ pati akan berikatan dengan air. Proses fermentasi akan menyebabkan hidrolisis area amorf yang menyebabkan pecahnya ikatan intermolekuler hydrogenkarena adanya penuruna gugus $\mathrm{OH}$ bebas. Hal tersebut memacu menurunnya penyerapan air dan penurunan pengembangan (swell) ketika pati dipasankan.

\section{Daya serap air}

Daya serap air atau kapasitas penyerapan air digunakan untuk mengukur kemampuan tepung dalam menyerap air dengan cara disentrifuge, serta menentukan jumlah air yang tersedia untuk proses gelatinisasi pati selama pemasakan.Daya serap air (water absorption) merupakan salah satu dari berbagai faktor yang mempengaruhi kualitas tepung. Water absorption atau daya serap pada tepung merupakan kemampuan tepung dalam menyerap air. Ukuran partikel, kadar air dan perbedaan kandungan kimia bahan mempengaruhi daya serap air (Mulyandari, 1992 dalam Rufaizah, 2011). Kapasitas penyerapan air merupakan kemampuan dalam menyerap air dan menahannya dalam suatu sistem pangan. Penyerapan dan pengikatan air merupakan salah satu sifat protein. Kapasitas penyerapan air menentukan jumlah air yang tersedia untuk 
proses gelatinisasi pati selama pemasakan. Bila jumlah air kurang maka pembentukan gel tidak mencapai kondisi optimum.

Hasil analisis statistik menunjukkan bahwa secara umumpenggunaan konsentrasi starter 2,5, 5, 7,5, 10, 12,5 dan $15 \%$ memberikanhasil yang berbeda nyata $(P>0,05)$ terhadap daya serap air,demikian juga dengan variasi lama fermentasi 24,48 dan 72 jammemberikan hasil yang berbeda nyata $(P<0,05)$. Berdasarkan hasil Uji lanjut bisa dilihat pada tabel 2. berikut ini:

Tabel 2. Daya Serap AirTepung Sorghum Terfermentasi Menggunakan Starter Yeast Indigenous Sorgum Dengan Variasi Kensentrasi Starter Dan Lama Fermentasi

$$
\text { Daya serap air (\%) pada jumlah starter yang digunakan (5) }
$$

\begin{tabular}{|c|c|c|c|c|c|c|}
\hline \\
\hline $\begin{array}{l}\text { lama } \\
\text { fermentasi }\end{array}$ & $2,5 \%$ & $5 \%$ & $7,5 \%$ & $10 \%$ & $12,5 \%$ & $15 \%$ \\
\hline $24 \mathrm{jam}$ & $66.37 \pm 0,53 \mathrm{Aa}$ & $66.69 \pm 0,53 \mathrm{Ab}$ & $66.26 \pm 0,53 \mathrm{Aa}$ & $67.39 \pm 0,53 \mathrm{Ad}$ & $67.59 \pm 0,53 \mathrm{Ce}$ & $66.85 \pm 0,53 \mathrm{Ac}$ \\
\hline $48 \mathrm{jam}$ & $66.49 \pm 0,30 \mathrm{BC}$ & $66.98 \pm 0,30 \mathrm{Bd}$ & $66.96 \pm 0,30 \mathrm{Ba}$ & $67.40 \pm 0,30 \mathrm{Aa}$ & $66.83 \pm 0,30 \mathrm{Ba}$ & $66.75 \pm 0,30 \mathrm{Bb}$ \\
\hline $72 \mathrm{jam}$ & $66.69 \pm 0,62 \mathrm{Cb}$ & $67.58 \pm 0,62 \mathrm{Cd}$ & $67.53 \pm 0,62 \mathrm{Cb}$ & $67.42 \pm 0,62 \mathrm{Aa}$ & $66.45 \pm 0,62 \mathrm{Ac}$ & $66.15 \pm 0,62 \mathrm{Cd}$ \\
\hline
\end{tabular}

Keterangan: Subscript yang sama pada kolom yang sama dan superscriptyang sama pada baris yang sama menunjukkan tidak berbeda nyata pada kepercayaan $95 \%$.

Hasil penelitian menunjukkan bahwa dengan semakin lamanya fermentasi dan semakin banyak starter yang ditambahkan menyebabkan adanya peningkatan kemapuan menyerap air. Buwono et al, 2018 menyatakan hal sama dimana waktu fermentasi pisang yang semakin meningkat akan meningkatkan kemapuan menyerap air dari tepung pisang. Hal yang sama dilaporkan oleh Gong et al. (2019) dimana dengan semakin lama fermenatsi kentang kemampuan menyerap air tepung kentang semakin meningkat. Peningkatan kemampuan menyerap air dari tepung sorgum terfermentasi bisa terjadi karena adanya modifikasi makromolekul, dimana adanya pemecahan ikatan glikosidik pati sehingga gugus hidrofilik akan lebih banyak kontak dengan air (Oloyede et al., 2016) atu bisa disebabkan adanya peningkatan gugus hidrofilik dari protein (Akubor \& Chukwu, 1999).

\section{Densitas Kamba}

Nilai densitas kamba (Tabel 5) diperoleh dari perbandingan antara total berat wadah dan sampel dengan volume wadah yang digunakan. Nilai densitas kamba yang semakin rendah menunjukkan bahwa sampel yang diuji, porositasnya tinggi atau bentuknya semakin berongga. Secara umum, densitas kamba produk tepung sorgum terfermentasi berkisar antara $0,61-0,76 \mathrm{~g} / \mathrm{ml}$. Hasil analisis statistik menunjukkan bahwa secara umum penggunaan konsentrasi starter 2,5, 5, 7,5, 10, 12,5 dan 15\% memberikan hasil yang 
berbeda nyata $(P>0,05)$ terhadap densitas kamba,sedangkan lama fermentasi (24,48 dan 72 jam) memberikan hasil yang tidak berbeda nyata $(P<0,05)$.

Tabel 5. Densitas KambaTepung Sorghum Terfermentasi Menggunakan Starter Yeast Indigenous Sorgum Dengan Variasi Konsentrasi Starter Dan Lama Fermentasi Densitas Kamba (g/ml) pada jumlah starter yang digunakan (\%b/v)

\begin{tabular}{|c|c|c|c|c|c|c|}
\hline $\begin{array}{l}\text { lama } \\
\text { fermentasi }\end{array}$ & $2,5 \%$ & $5 \%$ & $7,5 \%$ & $10 \%$ & $12,5 \%$ & $15 \%$ \\
\hline $24 \mathrm{jam}$ & $0.61 \pm 0,07 \mathrm{Aa}$ & $0.61 \pm 0,07 \mathrm{Ab}$ & $0.63 \pm 0,07 \mathrm{Ab}$ & $0.71 \pm 0,07 \mathrm{Ac}$ & $0.75 \pm 0,07 \mathrm{Ad}$ & $0.79 \pm 0,07 \mathrm{Ae}$ \\
\hline $48 \mathrm{jam}$ & $0.61 \pm 0,06 \mathrm{Aa}$ & $0.63 \pm 0,06 \mathrm{Ab}$ & $0.64 \pm 0,06 \mathrm{Ab}$ & $0.7 \pm 0,06 \mathrm{Ac}$ & $0.73 \pm 0,30 \mathrm{Ad}$ & $0.79 \pm 0,30 \mathrm{Ae}$ \\
\hline $72 \mathrm{jam}$ & $0.59 \pm 0,05 \mathrm{Aa}$ & $0.65 \pm 0,05 \mathrm{Ab}$ & $0.64 \pm 0,62 \mathrm{Ab}$ & $0.7 \pm 0,05 \mathrm{Ac}$ & $0.71 \pm 0,05 \mathrm{Ad}$ & $0.77 \pm 0,05 \mathrm{Ae}$ \\
\hline
\end{tabular}

Hasil penelitian menunjukkan bahwa semakin meningkatnya jumlah starter nilai densitas Kamba semakin meningkat. Steve (2012) melaporkan hal yang sama pada fermentasi gandum, dimana gandum yang difermentasi mempunyai nilai densitas Kamba yang lebih besar dibandingkan yang tidak difermentasi. sorgum yang difermentasi akan mengalami perombakan granula pati menjadi bentuk yang lebih sederhana karena aktivitas enzim oleh yeast, sehingga granula pati terhidrolisis dan menyebabkan granula berlubang. Selain itu, ikatan pati seperti amilosa dan amilopektin juga melemah sehingga didominasi dengan daerah amosphous pada granula pati.Densitas kamba dipengaruhi oleh ukuran partikel bahan sehingga densitas kamba produk akan lebih rendah dengan ukuran partikel yang lebih kecil. Densitas kamba merupakan salah satu sifat fisik yang penting untuk mengetahui porositas suatu benda solid. Densitas kamba ditentukan untuk dapat mengatur proses penyimpanan barang, jumlah volume, jenis transportasi dan jenis pengemasan pada bahan pangan.

\section{KESIMPULAN}

Fermentasi sorgum dengan menggunakan starter yeast yang diisolasi dari sorgum menunjukkan adanya perbedaan pengaruh lama fermentasi dan jumlah starter yang digunakan terhadapa karakateristik fisik dan kimia tepung sorgum. Berdasarkan karakteristik fisik dan kimia (kadar air, kadar pati, swelling power, kemampuan menyerap aid an densitas kamba), perlakun yang terbaik adalah penggunaan starter $5 \%$ dengan lama fermentasi 72 jam. 


\section{DAFTAR PUSTAKA}

AACC. 2000. Approved Methods of American Association of Cereal Chemists. American Association. 15th Edn. Arlington, USA

Akubor, P. I., \& Chukwu, J. K. 1999. Proximate composition and selected functional properties of fermented and unfermented African oil bean (Pentaclethra macrophylla) seed flour. Plant Foods for Human Nutrition, 54(3): 227-238

Alka, S., Neelam, Y. dan Shruti, S. 2012. Effect of fermentation on physicochemical properties and in vitro starch and protein digestibility of selected cereals. International Journal of Agricultural and Food Science 2(3): $66-70$.

Ashari D., Wahyuni S., dan Faradila F.R.H. 2018. Review: pengaruh proses modifikasi terhadap karakteristik tepung keladi termodifikasi Jurnal Sains dan Teknologi Pangan, 3(6): 1736-1744

Badan Standardisasi Nasional. 2002. Standar Nasional Indonesia (SNI) 01-3157 : 2002 - Sorgum

Buwono N. M., Amanto S. B., and Widowati E. 2018. Study of Physical, Chemical, and Sensory Characteristics of Modified Square Banana Flour (Musa balbisiana). Indonesian Food and Nutrition Progress, 15 (1). Retrived: http://journal.ugm.ac.id/ifnp

Correia, I., Nunes, A., Guedes, S., Baros, A.S. dan Delgadillo, I. 2010. Screening of lactic acid bacteria potentially useful for sorghum fermentation. Journal of Cereal Science. 52: 9-15.

Darmawan R.M., Andreas P., Jos B. dan Sumardiono S., 2013. Modifikai ubi kayu dengan proes fermentasi menggunakan starter L. casei untuk produksi pangan. Jurnal Teknologi Kimia dan Industri; 2(4);137-145

Fadlallah, O.E., El Tinay, A.H dan Babiker, E.E. 2010. Biochemical characteristics of sorghum flour fermented and/or supplemented with chickpea flour. International Journal of Biological and Life Sciences 6: 21 23.

Fennema, Owen R. 1996. Food Chemistry Third Edition. Marcel Dekker Inc. New York

Gong S., Xie F., Lan X., Zhang W., Gu X., and Wang Z. 2019.Effects of Fermentation on Compositions, Color, and Functional Properties of Gelatinized Potato Flours. Journal of Food Science. Retrived from: https://www.researchgate.net/publication/337543592. DOI: 10.1111/1750-3841.14837

Hidayah. Z, Kartiwan. (2018). Pemanfaatan isolat indigenous sorgum dalam pembuatan mosof serta aplikasi mosof dalam pembuatan produk berbasis pangan lokal. Laporan peneltiian Strategi Nasional

Ibrahim, F.S., Babiker, E.E., Yousif, N.E. dan el Tiney, A.H. 2005. Effect of fermentation on biochemical and sensory characteristic of sorghum flour supplemented with whey protein. Food Chemistry 92: 285-292.

Koswara. 2009. Teknologi Modifikasi Pati. Ebook Pangan

Kusnandar F. 2010. Teknologi Modifikasi Pati dan Aplikasinya di Industri Pangan. Retrived from: http://itp.fateta.ipb.ac.id/ 
Leach HW, Mc Cowen LD, Schoch TJ.1959. Structure of The Starch Granules. Cereal Chem. 36 : 534 - 544

Muchtadi, Tien R. dan Sugiyono. 1992. Petunjuk Laboratorium Teknologi Proses Pengolahan Pangan, PAU Pangan dan Gizi IPB. Bogor

Mulyandari, S.H. 1992. Kajian Perbandingan Sifat-Sifat Pati Umbi-Umbian Dan Pati Biji- Bijian.IPB, Bogor dalam Rufaizah, U. 2011. Pemanfaatan Tepung Sorghum (Sorghum bicolor Moench) Pada Pembuatan Snack Bar Tinggi Serat Pangan dan Sumber Zat Besi Untuk Remaja Puteri. Deparemen Gizi Masyarakat Fakultas Ekologi Manusia. IPB. Bogor

Numfor, F.A., Walter Jr, W.M., and Schwartz, S.J. 1995. Physicochemical Change in Cassaa Starch and Flour Associated with Fermentation: Effect on Textural Properties. Starch/Starke 47(3): 86-91

Ojokoh A. O., Alade R. A. , Ozabor P. T. * and Fadahunsi.I. F. 2020. Effect of fermentation on sorghum and cowpea flour blends. Journal of Agricultural Biotechnology and Sustainable Development. 12(2): 39-49, Retrived from http://www.academicjournals.org/JABSD. DOl: 10.5897/JABSD2019.0365

Oloyede, O. O., James, S., Ocheme, O. B., Chinma, C. E., \& Akpa, V. E. 2016. Effects of fermentation time on the functional and pasting properties of defatted Moringa oleifera seed flour. Food Science \& Nutrition, 4(1): 89-95

Setiarto RHB, Widhyastuti N. 2016. Pengaruh Fermentasi Bakteri Asam Laktat Terhadap Sifat Fisikokimia Tepung Gadung Modifikasi (Dioscorea hispida). Jurnal Litbang Industri. 6(1): 61-72.

Steve I.O. 2012 Influence of germination and fermentation on chemical composition, protein quality and physical properties of wheat flour (Triticum aestivum). Journal of Cereals and Oil seeds, 3(3): 35-47. Retrived: http://www.academicjournals.org/JCO DOI: 10.5897/JC012.015

Suarni,. 2005. Teknologi Pengolahan Jagung. Prosiding Seminar Nasional Teknologi Inovatif Pascapanen untuk Pengembangan Indusri Berbasis Pertanian. P. 521-536.

Sudarmadji, S; B. Haryono dan Suhardi. 1989. Analisa Bahan Makanan dan Pertanian. Penerbit Liberty. Yogyakarta.

Wani, A. A., Singh, P., Shah, M. A., Schweiggert-Weisz, U., Gul, K., dan Wani, I. A. 2011. Rice Starch Diversity: Effects on Structural, Morphological, Thermal, and Physicochemical Properties $\pm a$ Review. Comprehensive Reviews in Food Science and Food Safety. 11,: 417-436. 